\title{
Marketing communication strategy Sawah Pematang Johar tour in improving tourist visits
}

\author{
Venna Melinda Sari ${ }^{\text {a, },{ }^{*} \text {, Akhyar Anshori }}{ }^{\text {b,2 }}$ \\ ${ }^{a}$ University of Muhammadiyah Sumatera Utara, Jl. Kapten Muchtar Basri No.3, Glugur Darat II, Kec. Medan Tim., Kota Medan, Sumatera Utara 20238 \\ 1 vennamelindasari24@gmail.com*; ${ }^{2}$ akhyaransori@umsu.ac.id \\ * corresponding author
}

Article history

Received 09-10-2021

Revised 10-11-2021

Accepted 11-11-2021

\section{Keywords}

Marketing Communication Strategy

Tourism

Increase Tourists

\begin{abstract}
Tourism objects are one of the business fields that are developing so fast and creating competition between one tourist attraction and another in reaching visitors or tourists. Tourist attractions are actively developing to improve existing tourist locations continuously and make updates related to marketing strategies. The purpose of this study was to determine the marketing communication strategy for Sawah Pematang Johar tourism to increase tourist visits. This study used the descriptive qualitative method. Data obtained from observation, interviews, and documentation using descriptive analysis techniques, which describe the events under study. In this study, the number of informants was 5 people, namely the owner of the rice fields, field officers, to tourists. The research location is in the tourism village of the Pematang johar rice field, Deli Serdang Regency. The results showed that in marketing, the village government used a communication strategy to attract tourists in three ways, namely promotion through social media in the form of Facebook, Instagram, YouTube, MU television broadcasts, and word of mouth. The second activity is a place in the form of a comfortable, beautiful, and natural place. The third activity Price is in the form of very affordable entrance ticket prices. The second activity is a place in the form of a comfortable, beautiful, and natural place. The third activity Price is in the form of very affordable entrance ticket prices. The second activity is a place in the form of a comfortable, beautiful, and natural place. The third activity Price is in the form of very affordable entrance ticket prices.
\end{abstract}

This is an open access article under the CC-BY-SA license.

\section{Introduction}

Tourist objects are one of the most rapid business developments in the tourism sector, causing competition to attract tourists from one tourist attraction to another. This is due to changes in the business environment that are fast and make tourist attractions must continue to be active in developing existing tourist locations and continuously make updates related to strategies in marketing them. Medan City is one of the city destinations for tourists, both local tourists and foreign tourists. The city of Medan has various historical places that can be visited by tourists; besides that, the people of Medan City have very strong customs with historical values. Besides, the people of Medan City have a unique culture to learn. So that visitors can enjoy the diversity of society (Neal, 2009).

The development of tourist objects in addition to places that contain history (historical), the latest tourism development has also begun, both in Medan City itself, as well as the areas around Medan City which are geographically located in Deli Serdang Regency. One area is Pematang Johar village in the Labuhan Deli sub-district, Deli Serdang district. The community and village government in 
Pematang Johar exploit their natural potential by building a new tourist destination by arranging the rice fields into tourist attractions and has become an icon for the village. The calm atmosphere typical of the countryside, makes us feel comfortable when we are in the tourist location of Pematang Johar.

The development of tourist objects in addition to places that contain history (historical), the latest tourism development has also begun, both in Medan City itself, as well as in the areas around Medan City which are geographically located in Deli Serdang Regency. One of the areas is Pematang Johar village in Labuhan Deli sub-district, Deli Serdang regency. The community and village government in Pematang Johar exploit their natural potential by building a new tourist destination by arranging the rice fields into tourist attractions and has become an icon for the village. The calm atmosphere is typical of the countryside, making us feel comfortable when we are in the tourist location of Pematang Johar (Laureto et al., 2015).

The development of tourist objects in addition to places that contain history (historical), the latest tourism development has also begun, both in Medan City itself, as well as the areas around Medan City which are geographically located in Deli Serdang Regency. One of the areas is Pematang Johar village in Labuhan Deli sub-district, Deli Serdang regency. The community and village government in Pematang Johar take advantage of its natural potential by building a new tourist destination by arranging the rice fields into tourist attractions and has become an icon for the village. The calm atmosphere typical of the countryside, makes us feel comfortable when we are in the tourist location of Pematang Johar. as well as the area around Medan City which is geographically located in the Deli Serdang Regency. One of the areas is Pematang Johar village in Labuhan Deli sub-district, Deli Serdang regency (Santos-Roldán et al., 2020).

The community and village government in Pematang Johar exploit their natural potential by building a new tourist destination by arranging the rice fields into tourist attractions and has become an icon for the village. The calm atmosphere typical of the countryside, makes us feel comfortable when we are in the tourist location of Pematang Johar. as well as the area around Medan City which is geographically located in the Deli Serdang Regency. One of the areas is Pematang Johar village in Labuhan Deli sub-district, Deli Serdang regency. The community and village government in Pematang Johar exploit their natural potential by building a new tourist destination by arranging the rice fields into tourist attractions and has become an icon for the village. The calm atmosphere typical of the countryside, makes us feel comfortable when we are in the tourist location of Pematang Johar (Pencarelli, 2020).

The community and village government in Pematang Johar take advantage of its natural potential by building a new tourist destination by arranging the rice fields into tourist attractions and has become an icon for the village. The calm atmosphere is typical of the countryside, making us feel comfortable when we are in the tourist location of Pematang Johar. The community and village government in Pematang Johar exploit their natural potential by building a new tourist destination by arranging the rice fields into tourist attractions and has become an icon for the village. The calm atmosphere typical of the countryside, makes us feel comfortable when we are in the tourist location of Pematang Johar.

As a tourism village that utilizes rice fields, by involving the community as part of its management, it is necessary to continue to be able to hone its management both through government and private roles, so that this tourist destination can become one of the mainstays that can create welfare for the surrounding community. The success of a tourist spot is not only seen from what is produced but from the communication role of the marketing division that actively markets the company's products. Company goals can be achieved by increasing sales through marketing communications. Thus, this study aims to find out about the Marketing Communication Strategy of Pematang Johar Rice Field Tourism in Increasing Tourist Visits ". 


\section{Theorotocal Framework}

a) Marketing Communication Strategy

The Communication Strategy is a series of activities carried out by the Rice Field Tour using structured methods to achieve a goal. The marketing communication strategy is the decisions of the management regarding the elements of the promotion mix because in general marketing communication uses the promotion mix. 3 steps must be taken for successful marketing communications:

Activities carried out using a structured way to achieve a goal are called a communication strategy. The basic concept of marketing communication is a management decision related to promotion which generally uses mixed promotion (promotion mix). According to Leith \& Morison, (2004), marketing communication can be said to be successful by taking three steps, namely: (1) Segmentation, (2) Targeting, (3) Positioning.

According to Finne \& Grönroos (2017), marketing communication is an effort to convey messages to target audiences or consumers about the existence of products in the market. Marketing communication in this study uses a theory known by Don E. Schultz, namely integrated marketing communication (IMC).

Marketing communication is an attempt to make all promotional and marketing activities in the company to produce a positive image that is consistent with consumers. From several definitions of marketing communication put forward by several previous experts, it can be said that marketing to consumers using certain media, starting from marketing products, prices, distribution, and promotions used by companies in the core of marketing communication in attracting consumers. This is important so that consumers can be interested in buying or trying the products or services offered. Marketing communication is also a means of informing, reminding, and persuading consumers about products sold by a company, either directly or indirectly. There are two forms of marketing communication, the first is an advertising and the second is promotion (Todorova, 2015).

\section{b) Traveler}

Tourists visiting an area usually really want to spend their time relaxing, refreshing their minds, and wanting to get away from the routine of daily life. So it can also be said that a tourist is someone who travels from another place far from his home not for reasons of home and office. Tourists according to their nature (Kusumaningrum, 2009: 17-18) (Han \& Hyun, 2018).

A tourist is someone who is visiting a place or area. Tourists who visit will spend a lot of time on vacation, relaxing, and getting away from the routine activities of their daily life. Thus, it can be said that a tourist is someone who is on his way from one place to another. According to Kusumaningrum, there are 4 types of tourists based on their characteristics, namely idealistic modern tourists, namely tourists who are interested in multinational culture and individual exploration of nature. second, modern materialist tourists, namely tourists who only seek profit as a group. Third, idealistic traditionalist tourists, namely tourists who are interested in traditional sociocultural life and who are interested in nature that is not disturbed or pure (F. D. Putra \& Smolek, 2020).

Tourists traveling have various purposes, one of which is to have fun. The following are the types and characteristics of tourists, namely: (a) A local tourist, namely someone who travels to an area within his own country, (b) International tourist, namely someone who travels to an area outside the country, (c) Holiday tourist namely someone who travels for vacation or fun, (d) Business tourist that is, someone traveling for trade or professional affairs, (e) Common interest tourists namely someone who travels with a special purpose, such as scientific studies, visiting family, medical treatment, and so on, (f) Individual tourist that is, someone who travels to a tourist spot individually, (g) Group tourist namely someone who travels to tourist attractions in groups.

Then two factors influence the number of tourists visiting, namely the first aspect of the offer, which includes attractiveness, transportation, facilities, and institutions. The second factor is the aspect of tourism demand, which affects economic factors, small and medium enterprises, private companies, and the government sector. 
In general, tourists are a group of people who come to an area to travel, not to live permanently in the destination, work for wages, and so on. A visitor (visitor) is a person who comes to a place or country without any purpose except to do work that is paid for. According to Baiquini (2011), there are several tourist motivations, namely: (a) Physical motivation, the goal is to get something related to the desire to restore physical condition by relaxing, resting, exercising, and so on, (b) Cultural Motivation, is related to a person's personal desire to see and know a country or other area, especially about society and its culture, (c) Interpersonal motivation, namely someone's desire to visit family, new friends, and others. This motivation is related to running away from the routine of everyday life, (d) Motivation for Status and Self-Esteem, which is to have a motive to show off to show one's position and social status in society.

Tourists are people who travel to a place to travel and not to earn money or work. The tourist objects were chosen by tourists also vary, depending on the tourist's motivation to visit a tourist destination that is closely related to the tourist activities that the tourist will choose. Foreign tourists are tourists who live in a country and travel to another country, not their place of residence to travel. Meanwhile, domestic tourists are tourists who travel in the area or place. Transit tourists are tourists who travel to a foreign country, which is not their will because they are compelled to stop by the foreign country as a link to the foreign country they are aiming for. Besides, business tourists are foreigners traveling to get an assignment or a job. After the work is completed, the business traveler can carry out holiday activities in a foreign country (A. Putra \& Ochirov, 2020).

Tourist activities to travel and not to earn money or work are called tourists. The choice of tourist attractions is selected based on the interest of tourists in visiting that place. Tourists who live in a place or country that is not their place of origin are called foreign tourists. Meanwhile, tourists who go to an area within the country are called domestic tourists. Tourists who go to an area to get a job or assignment are called business tourists.

\section{Method}

The author uses a qualitative approach in carrying out this research, namely research through observation, interviews, or document review and with a descriptive nature. Interviewing is the process of obtaining information for research purposes in a way that answers face-to-face between the interviewer and the informant or the person being interviewed, with or without using an interview guide, where the interviewer and the informant are involved in a relatively long social life (Katuna, 2019).

This research uses qualitative methods, namely by researching through observation, interviews, and document review. The qualitative method used is descriptive by using interviews. According to Turner (2010), the interview is a question-and-answer process to obtain information on research conducted face-to-face, with or without interview guidelines, where the interviewer and the informant are involved in a relatively long social life. The informants in this study were rice field tourism managers and tourists who were visiting the johar bund (Sarifudin et al., 2020).

\section{Results and Discussion}

\section{a) Marketing Communication Strategy}

A strategy is defined as a process in planning and determining by leaders who focus on long-term organizational goals by arranging ways to achieve these goals (Naraian, 2010). Meanwhile, according to Jandevi \& Zareen (2020) marketing communication is two-way communication in which there is an exchange of information to improve the marketing process so that it functions efficiently and effectively. Marketing communication is used as a means to persuade, inform, and remind consumers of the products sold by the company, either directly or indirectly.

The mix in marketing communication consists of 4Ps, namely, firstly the product (product) which is related to quality, features, design, style, shape, packaging, service size, etc. Second, the price (price) which relates to the amount of money the customer is paying. pay for these products, with three determining factors, namely product quality, level of competition, and promotional 
activities. Third, place (place), which is a place to distribute products to consumers, and the last one is promotion, which is an action taken to create interest in the product (Eagle et al., 2014).

From the interview above We can conclude that marketing communication uses a strategy to market the johar rice field tourism with the 3P system, namely Promotion, Place, Price.

\section{1) Promotion (promotion)}

In Pematang johar rice field tourism, the manager carries out promotions through social media Facebook, Instagram, YouTube, even MU (Muhammadiyah) broadcast television, and the manager also implements the DMK system, namely from the mouth of the mouth. Managers are very guarding officers at tourist locations so that they continue to greet and prioritize tourists rather than their duties. The three friendly tourist officers will also be very satisfied and feel comfortable in being inside and that certainly greatly affects a good image for this johar rice field tourist spot, especially to launch promotions through the DMK system (Fadillah \& Jandevi, 2020).

Sawa tourism Pematang johar has his own social media account. Accounts belonging to the government/village also promote this tourist spot, as well as some people who blog at the location, indirectly that person also promotes this rice field tour. Also, MU television broadcast participated in showing this tour in detail and detail.

We can type tourism in the Pematang Johar rice field in the search column on Facebook, so a very beautiful and beautiful view will appear. Then the Instagram account "Pematang johar rice field tourism" also shows pictures of tourist sites and visitors displaying happy faces.

\section{2) Place (the place)}

This tourist spot located in Pematang Johar village, Deli Serdang sub-district is very comfortable and safe. The manager also provides all the facilities that tourists need, such as restaurants, prayer rooms, toilets, huts for resting, as well as very unique photo spots. Tourist attractions in this inland area do not deter tourists from visiting because tourists themselves feel satisfied with the place that is served. From the beautiful view and beautiful restaurant which provides all the food that tourists want, a very comfortable prayer room, and very clean accommodation and a place to make tourists satisfied.

\section{3) Price (price)}

The price set by the tour manager is also very cheap, only Rp. 5000 price of admission and does not limit the time of tourist visits. By paying 5000 rupiahs, tourists will be very satisfied to be in this tourist spot. From the results of interviews with tourists, the researchers concluded that the low and affordable prices for all groups, determined by this manager, really greatly increase the attractiveness of tourists to visit.

\section{4) Product (product)}

Tourist facilities are also very helpful in attracting tourists. When the facilities provided are sufficient and even make tourists satisfied, tourists will not give up on visiting another time. Facilities that satisfy tourists such as clean toilets and a comfortable prayer room make tourists feel at home visiting, and tourists don't need to bring supplies or snacks out of the location anymore because of the restaurant in the middle of the rice fields and people selling in tourist attractions.

\section{b) Tourist Interest}

A tourist is someone who travels. The term tourists are understood as people who come to a place that has tourist dance power. This is stated in the Law of the Republic of Indonesia Number 10 the Year 2009 concerning Tourism. Tourist visits are very influential in these tourist attractions. Because if no tourists are visiting the tourist spot will be closed. In this Pematang johar rice field tour, there are quite a lot of tourists visiting, as evidenced by the very large currency income. From the results of interviews and observations, the researcher concluded that in this johar bund tour, there were quite a lot of tourists who were interested in coming, they did not know the circle because during the interview the researchers saw children, adolescents, and adults who came to visit this tour. 
The researcher concluded that most of the tourists who are interested in coming besides the place are clean and comfortable, the price set by the manager is one of the interests of tourists. Researchers will describe several important points to attract tourists, including:

\section{1) Tourist attraction}

A tourist place or tourist attraction is a place of recreation or a place of tourism. A tourist spot is also a location that is used as a tourist activity. Tourist attractions are a weapon for entrepreneurs who want to open tourist attractions because a good place can attract visitors to come.

In this Pematang Johar rice field tour, the researchers got the conclusion that tourists visit because they want to enjoy a comfortable place and create peace of mind and heart. From here we can see that this rice field tour has succeeded in creating a place that attracts tourists to visit.

\section{2) Tourist Location Facilities}

Tourist facilities are also very helpful in attracting tourists. When the facilities provided are sufficient and even make tourists satisfied, tourists will not give up on visiting another time. From the results of observations and interviews, the researchers concluded that the Pematang Johar rice field tourist spot can provide very satisfying facilities for tourists such as clean toilets and a comfortable prayer room to make tourists feel at home visiting, and tourists don't need to bring supplies or snacks out of the location anymore because of the restaurant in the middle of the rice fields. and people selling in tourist attractions. The researcher also concluded that this johar bund tour had fairly complete facilities so that this tour succeeded in attracting tourists from the existing facilities at the tourist site.

\section{3) Promotion of Tourist Locations}

Actions taken in informing a product or service to potential consumers or tourists who will become the target market are called promotions. All marketing efforts have a function in providing or convincing consumers about the usefulness of a product or service that aims to attract consumers to buy or continue offers at a certain price.

The researcher concludes that the promotion carried out by the tour manager has been successful because it is evident from the many tourist visits to this johar rice field tour.

4) Price

Price is a determining component in a company because the price is related to the company's income and is an influence on the company. Pematang johar rice field tourism, researchers can conclude that this place has succeeded in attracting tourists from prices that are affordable to all groups. This is evident from the sizeable income of tourist visits every month.

Tourist activities to travel and not to earn money or work are called tourists. The choice of tourist attractions is selected based on the interest of tourists in visiting that place. Tourists who live in a place or country that is not their place of origin are called foreign tourists. Meanwhile, tourists who go to an area within the country are called domestic tourists. Tourists who go to an area to get a job or assignment are called business tourists.

It can be concluded that interest is one of the psychological aspects that has the most important role in fostering behaviour. The feeling of being attracted to something that is based on a sense of liking so that it generates attention, making you want to be involved with something is called interest. Interest has two elements, namely motive, and attention. A motive is an effort that encourages and makes someone's will emerge from within him so that it causes someone to do something with his interest. Meanwhile, attention is the concentration of awareness of an object. Interest arises and increases after a person has information about something, thus it can be said that interest generally has already recognized things that are already known (Zeithaml, 1988).

\section{Conclusion}

The Marketing Communication Strategy of Pematang Johar Rice Tourism in attracting tourists, the researcher concludes that the marketing communication activities carried out by the village 
government, the manager is 4P marketing communication, namely Promotion (promotion) where the manager promotes tourist attractions through social media Facebook, Instagram, YouTube, and MU television broadcasts; and tourist communication by word of mouth.

\section{Acknowledgment}

Thanks, are extended to all elements who have helped in the completion of this research. Thank you also to the Communication Science Study Program of the Muhammadiyah University of North Sumatra which has been a means to obtain knowledge that is always superior, smart, and reliable.

\section{References}

Eagle, L., Dahl, S., Czarnecka, B., \& Lloyd, J. (2014). Marketing Communications. In Marketing Communications. https://doi.org/10.1017/9781315848860

Fadillah, D., \& Jandevi, U. (2020). Media-social behavior of Muhammadiyah members in China in the framework of Alexander Wendt's international communication constructivism. Journal of Social Studies (JSS), 16(1), 51-64. https://doi.org/10.21831/jss.v16i1.34604

Finne, Å., \& Grönroos, C. (2017). Communication-in-use: customer-integrated marketing communication. European Journal of Marketing. https://doi.org/10.1108/EJM-08-2015-0553

Han, H., \& Hyun, S. S. (2018). Role of motivations for luxury cruise traveling, satisfaction, and involvement in building traveler loyalty. International Journal of Hospitality Management. https://doi.org/10.1016/j.ijhm.2017.10.024

Jandevi, U., \& Zareen, M. (2020). Cross-cultural communication of the Indonesian students in China. International Journal of Communication and Society, 2(2), 79-85. https://doi.org/10.31763/ijcs.v2i2.96

Katuna, B. (2019). Interview Guide. In Degendering Leadership in Higher Education. https://doi.org/10.1108/978-1-83867-130-320191009

Laureto, L. M. O., Cianciaruso, M. V., \& Samia, D. S. M. (2015). Functional diversity: An overview of its history and applicability. In Natureza e Conservacao. https://doi.org/10.1016/j.ncon.2015.11.001

Leith, P., \& Morison, J. (2004). Communication and dialogue: what government websites might tell us about citizenship and governance. International Review of Law, Computers \& Technology. https://doi.org/10.1080/13600860410001674715

Naraian, S. (2010). General, special and ... inclusive: Refiguring professional identities in a collaboratively taught classroom. Teaching and Teacher Education. https://doi.org/10.1016/j.tate.2010.06.020

Neal, C. P. (2009). Marketing management. In Marketing Management. https://doi.org/10.4324/9781315842783-16

Pencarelli, T. (2020). The digital revolution in the travel and tourism industry. Information Technology and Tourism, 22(3). https://doi.org/10.1007/s40558-019-00160-3

Putra, A., \& Ochirov, A. (2020). The effect of watching political programs on islamic-based party political images among Muhammadiyah students. International Journal of Communication and Society, 2(2), 58-69. https://doi.org/10.31763/ijcs.v2i1.82

Putra, F. D., \& Smolek, S. (2020). Peace language and conflict resolution in harmony communication. International Journal of Communication and Society, 2(2), 86-93. https://doi.org/10.31763/ijcs.v2i2.134

Santos-Roldán, L., Canalejo, A. M. C., Berbel-Pineda, J. M., \& Palacios-Florencio, B. (2020). Sustainable tourism as a source of healthy tourism. International Journal of Environmental Research and Public Health, 17(15). https://doi.org/10.3390/ijerph17155353

Sarifudin, Evendi, H. H., Jumasa, M. A., Surjono, H. D., Hasana, S. N., Maharany, E. R., Setiawan, A., Wigati, S., Sulistyaningsih, D., Putri, N. W., Dwijayanti, R., Wisudawati, W., Sulistyowati, E., Rusli, M., Hermawan, D., Supuwiningsih, N., Simarmata, J., Mujiarto, Agung, A. A. G., ... Samatowa, U. (2020). Metode Penelitian Kuantitatif, Kualitatif, dan R \& D. In JPM : Jurnal Pendidikan Matematika. 
Todorova, G. (2015). Marketing communication mix. Trakia Journal of Science. https://doi.org/10.15547/tjs.2015.s.01.063

Turner, D. W. (2010). Qualitative interview design: A practical guide for novice investigators. Qualitative Report.

Zeithaml, V. A. (1988). Consumer Perceptions of Price, Quality, and Value: A Means-End Model and Synthesis of Evidence. Journal of Marketing. https://doi.org/10.2307/1251446 